\author{
Ali Mamat ${ }^{1 *}$, Muhamad Kamel Ali ${ }^{2}$ \\ ${ }^{12}$ Politeknik Sultan Mizan Zainal Abidin \\ $\supseteqq$ e-mail: alimatpdt@yahoo.com
}

\title{
Relationship of Work Satisfaction and Organizational Commitment: a Literature Review
}

\begin{abstract}
The enjoyment of working in an organization contribute to a positive impact in life. This also can be related to the individual job satisfaction. In fact, the job satisfaction including six elements namely salary, promotion, supervisor, job environment, colleagues and working conditions. Consequently, this study aims to investigate and identify the factors which influence job satisfaction in an organization by using document analysis with reference to previous study. However, the findings reveal a few factors that support the relationship between job satisfaction and organizational commitment among primary school assistant teachers. This gives clarity about the relevance of the relationship between the theories used in this study.
\end{abstract}

Keywords: Job satisfaction; Factor; Theory

\section{Hubungan Kepuasan Kerja dan Komitmen Organisasi: Satu Kajian Literatur}

\begin{abstract}
Keseronokan bekerja dalam organisasi menyumbang kepada kesan positif dalam kehidupan. Ini juga boleh dikaitkan dengan kepuasan kerja individu. Malah, kepuasan kerja termasuk enam elemen iaitu gaji, promosi, penyelia, persekitaran kerja, rakan sekerja dan keadaan kerja. Oleh itu, kajian ini bertujuan untuk menyiasat dan mengenal pasti faktor-faktor yang mempengaruhi kepuasan kerja dalam organisasi dengan menggunakan analisis dokumen yang merujuk kepada kajian terdahulu. Walau bagaimanapun, hasil kajian menunjukkan beberapa faktor yang menyokong hubungan antara kepuasan kerja dan komitmen organisasi di kalangan pembantu guru sekolah rendah. Ini memberikan kejelasan mengenai kaitan hubungan antara teori-teori yang digunakan dalam kajian ini.
\end{abstract}

Keywords: Kepuasan kerja; Faktor; Teori

Copyright (C) 2018 IICET (Indonesia) - All Rights Reserved

Indonesian Institute for Counseling, Education and Therapy (IICET)

\section{PENGENALAN}

Usaha memperkasakan sistem pendidikan sudah tentulah peranan sekolah dan institusi pendidikan semakin mencabar dan perlu berdaya saing. Untuk mendukung dan menggalas tanggungjawab ini maka ciri-ciri pendidik seperti berkredibiliti, beriltizam, berkepimpinan serta bermujahadah perlu sekali ada dalam kalangan mereka. Arnold \& Feldman (1986) menjelaskan, kepuasan kerja merupakan jumlah 
keseluruhan kesan positif yang dimliki oleh seseorang individu terhadap pekerjaan. Robbins (2000), menyatakan kepuasan kerja berkait dengan enam penentu iaitu faktor gaji, kenaikan pangkat, penyelia, suasana pekerjaan, hubungan rakan sekerja dan keadaan pekerjaan itu sendiri. Beliau turut mempercayai bahawa pekerja-pekerja yang berpuas hati berkemungkinan menjadi warganegara yang mempunyai sikap yang positif terhadap hidup dalam organisasi dan masyarakat.

Kepuasan dari segi ganjaran seperti gaji, penghargaan dan kenaikan pangkat bergantung kepada keadilan dan persamaan yang mereka dapati dari pihak pentadbiran dan bertepatan dengan kehendak individu itu. Manakala kepuasan dari segi keadaan pekerjaan bergantung kepada kesesuaian kehendak fizikal manusia dan tahap pencapaian matlamat kerja yang diharapkan (Ali, Hassan \& Som 2017). Menurut Juhary Ali (1987), tonggak kecemerlangan sesebuah organisasi terletak pada jentera pengurusannya yang cekap dan berwawasan. Pengurusan yang cekap ini mempunyai hubungan yang signifikan antara kepuasan kerja dan komitmen terhadap organisasi. Bagaimanapun, tanpa pegawai dan kakitangan yang mengamalkan budaya kerja cemerlang.

Steer (1977) berpendapat prestasi sesebuah organisasi bukan sahaja dipengaruh oleh ciri-ciri organisasi itu sendiri seperti struktur dan teknologi, polisi dan amalan pengurusan, ciri-ciri persekitaraan seperti ekonomi dan politik, malahan ciri-ciri pekerja seperti prestasi kerja juga memainkan peranan yang penting. Justeru iti, amatlah mustahak untuk mengkaji dan memahami faktor-faktor kepuasan dan prestasi kerja mereka. Faktor kepuasan kerja perlu diambil perhatian yang serius supaya ia tidak memberi kesan terhadap hasil kerja organisasi dan seterusnya menjejaskan reputasi jabatan. Kejayaan sebuah organisasi berlaku apabila ahlinya sanggup mengorbankan masa serta usaha mereka dan komitmen akan meningkatkan lagi produktiviti, kualiti dan inovasi. Dalam masa yang sama tuntutan komitmen kerja dalam organisasi ditagih bagi memenuhi aspirasi negara. Menurut Mohd Salleh (2003), komitmen guru terhadap sekolah adalah merupakan satu sikap yang profesional dalam penyataan sejauhmanakah mereka menyayangi organisasi sekolah dan seterusnya ingin berusaha untuk meningkatkan prestasi organisasi. Komitmen yang diberikan bukan sahaja penting dalam menentukan kerja yang lebih efisien tetapi juga penglibatan yang komited amat bermakna supaya daya pengeluaran optimum dapat dicapai.

\section{LITERATUR REVIEW}

\section{Teori-teori Kepuasan Kerja}

\section{Teori Motivator-Hygiene Herzberg (1959)}

Teori ini dicetuskan oleh Frederick Herzberg dan rakan-rakannya (Herzberg et. al. 1959; Herzberg, 1966). Asas kepada teori ini adalah dari konsep hiraki keperluan sebagaimana teori hiraki keperluan oleh Abraham Maslow. Teori Herzberg menyatakan faktor-faktor yang mendorong kepada kepuasan kerja adalah berbeza dari faktor-faktor yang menyebabkan ketidakpuasan kerja. Faktor yang mendorong kepada kepuasan kerja adalah disebut sebagai faktor pendorong (motivational) yang meliputi kemajuan kerjaya, pengiktirafan, rasa tanggungjawab dan pencapaian. Faktor yang menyebabkan ketidakpuasan kerja adalah disebut sebagai faktor hygiene yang meliputi faktor seperti jaminan pekerjaan, polisi organisasi, hubungan kemanusiaan (interpersonal) dan keadaan pekerjaan. Herzberg menyatakan bahawa faktor pendorong berpotensi untuk memotivasikan pekerja kepada tahap prestasi yang lebih tinggi. Faktor tersebut menyediakan peluang untuk mencapai kepuasan peribadi. Namun ketiadaan faktor-faktor ini tidak akan menyebabkan pekerja merasa tidak puas hati. Ianya akan menyebabkan pekerja hanya mempunyai perasaan yang neutral terhadap pekerjaan mereka (Sazali, 2000).

\section{Teori Jangkaan Vroom (1964)}

Relevan dengan kajian kepuasan kerja Locke (1976). Aspek motivasi adalah elemen penting dalam pelakuan individu pekerja dan mempunyai alternatif untuk membuat pilihan sama ada baik atau pun tidak. Mempunyai formula untuk mengukur kepuasan iaitu Valens X Jangkaan Kepuasan. Valens ialah tindakan afektif individu pekerja terhadap matlamat. Jika individu berminat melakukan sesuatu kerja untuk 
mencapai matlamat, valensnya positif. Jika tidak berminat, valensnya negative. Pekerja yang statik, valensnya pula sifar. Jangkaan pula ialah kekuatan keyakinan pekerja untuk mencapai matlamat. Keyakinan berkait rapat dengan tindakan. Seseorang pekerja yang mempunyai tahap keyakinan yang kuat untuk mencapai tahap prestasi tertentu, maka individu tersebut akan berusaha untuk mencapainya. Contohnya, seseorang pekerja yang bekerja dengan bersungguh-sungguh akan diberikan kenaikan pangkat seperti apa yang dihajatinya. Elemen lain seperti gaji, suasana pekerjaan, rakan sekerja dan penyelia juga menjadi motivasi kepada kepuasan pekerja dan kekuatan keyakinan pekerja.

\section{Teori Keadilan (1965)}

Teori ini dibangunkan oleh Adams (1965) yang mengatakan bahawa input utama yang membawa kepada prestasi dan kepuasan kerja adalah darjah kepada keadilan atau ketidakadilan yang dirasakan oleh individu dalam situasi pekerjaannya. Sazali (2000), ketidakadilan (inequity) berlaku apabila persepsi individu mengatakan bahawa hasil dapatan (outcomes) kepada input adalah tidak sama dengan nisbah hasil dapatan seorang lain yang relevan. Kedua-dua input dan output adalah berdasarkan kepada persepsi individu. Umur, jantina, taraf pendidikan, status sosial dan usaha seseorang adalah contoh pembolehubah input berdasarkan persepsi individu. Hasil dapatan secara umum merujuk kepada ganjaran seperti gaji, status, jawatan atau pangkat. Luthans (1992), pada dasarnya nisbah keadilan atau ketidakadilan adalah bergantung kepada persepsi individu mengenai apa yang diberikan (input) berbanding apa yang diterima (output), dan dibandingkan dengan apa yang diberi dan diterima oleh orang lain.

\section{Teori Alderfer' ERG (1969)}

Terbentuk daripada teori hiraki keperluan Maslow dan teori Dua Faktor Herzberg. Alderfer mengubahsuai Teori Hirarki Maslow kepada tiga keperluan.

i. Keperluan Kewujudan - Menggabungkan keperluan fisiologi dan keselamatan dalam teori Maslow. Ciri-ciri yang berkaitan dengan pekerjaan dalam kategori adalah seperti upah, gaji, keselamatan kerja, kemudahan dan suasanan pekerjaan.

ii. Keperluan Pertumbuhan - Meliputi keinginan dihormati dan penampilan diri. Ia termasuk keperluan intrinsik individu. Pekerja yang menggunakan segala kemahiran dan kreativiti akan mencapai keperluannya dan diberikan penghormatan seperti kenaikan pangkat. Ini memberikan kepuasan pekerja melakukannya.

iii. Keperluan Perhubungan - Merangkumi hubungan dengan orang lain termasuklah rakan sekerja, penyelia, sahabat, keluarga dan orang bawahan. Keperluan ini jika dipenuhi mewujudkan ketenteraman hubungan di tempat kerja.

\section{METODOLOGI}

Tujuan kajian ini adalah untuk mengenal pasti teori yang mempengaruhi kepuasan kerja di kalangan organisasi. Untuk mencapai matlamat ini, kajian ini dijalankan secara kualitatif dalam bentuk analisa dokumen. Beberapa laporan kajian sebelumnya, prosiding persidangan, dan jurnal telah dirujuk sebagai kajian literatur, dan dianalisis dengan data yang dikumpul menggunakan jadual matrik (Strauss \& Corbin, 1994). Berdasarkan Sallabas(2013) dan Best \& Kahn(1998), kaedah analisa dokumen adalah alat yang paling sesuai untuk mengumpul maklumat dalam kajian kualitatif. Selain itu, Onwuegbuzie, Leech \& Collins (2012) percaya bahawa pembolehubah yang berkaitan dengan topik itu dapat dikenal pasti dengan melakukan kajian semula terhadap kajian literatur. Teknik ini digunakan, kerana ia adalah kaedah yang teratur untuk meninjau dan menilai dokumen dan sumber elektronik.

\section{DAPATAN KAJIAN DAN PERBINCANGAN}

Kajian bagi mengenal pasti akan kesan dari ciri-ciri demografi kepada tahap komitmen terhadap organisasi mencakupi aspek umur, status perkahwinan, taraf pendidikan, jantina, pangkat dan kekananan, tempoh perkhidmatan telah banyak dilakukan. Ciri-ciri demografi responden yang dilibatkan dalam kajian ini adalah mengenai jantina, umur, dan tempoh perkhidmatan. Hall et al.(1970), Steers (1977), dan 
Mowday et al. (1982) mendapati umur dan tempoh perkhidmatan tidak mempunyai hubungan dengan komitmen. Namun Angle dan Perry (1980) mendapati bahawa komitmen terhadap organisasi didapati mempunyai hubungan positif dengan umur dan jantina. Mazni (1996) mendapati perbezaan komitmen yang signifikan berdasarkan ciri-ciri peribadi seperti umur, tempoh perkhidmatan, serta jawatan, kecuali jantina. Kajian Sazali (2000) mendapati bahawa taraf pendidikan mempunyai kaitan dan perbezaan dari aspek kepuasan kerja. Beliau mendapati bahawa pegawai-pegawai kastam berkelulusan STPM/HSC mempunyai nilai min keseluruhan, kepuasan intrinsik dan kepuasan ekstrinsik yang terendah berbanding dengan pegawai yang mempunyai kelulusan yang lebih tinggi atau yang lebih rendah. Shamsirudin (2000) mendapati tahap pendidikan mempunyai hubungan positif dengan komitmen terhadap organisasi. Dapatan ini menunjukkan bahawa semakin tinggi tahap pendidikan, semakin tinggi komitmen terhadap organisasi.

Jamaliah (2002) mendapati bahawa kelayakan akademik dan kumpulan jawatan mempunyai perbezaan yang signifikan kepada komitmen kakitangan. Ahmad Zikrileh (2001) mendapati bahawa faktor demografi seperti gred jawatan dan taraf pendidikan mempunyai hubungan dan perbezaan dari segi komitmen pekerja terhadap organisasi. Tempoh perkhidmatan juga mempunyai hubungan positif dengan komitmen terhadap organisasi. Namun terdapat kajian yang mendapati pembolehubah umur dan jantina tidak mempunyai kaitan dengan komitmen (Steers, 1977). Taraf pendidikan didapati mempunyai hubungan negatif dengan komitmen (Morris \& Sherman, 1981). March dan Simon (1958) mendapati bahawa umur dan pengalaman seseorang pekerja meningkat, peluang baginya untuk menimbangkan dan mencari pekerjaan alternatif menjadi lebih terhad.

Komitmen terhadap organisasi dipersetujui oleh ramai cendiakawan dan penyelidik berkait rapat dengan kepuasan kerja seseorang individu. Amat penting kepuasan dibentuk dan dipelihara dalam memastikan komitmen penuh pekerja untuk memberikan yang terbaik dalam menjalankan tugas. Marsh dan Mannari (1977) menyatakan kepuasan kerja adalah peramal penting bagi komitmen sepanjang hayat di kalangan pekerja Jepun. Kepuasan kerja juga dikenal pasti sebagai titik tolak kepada komitmen organisasi di kalangan pekerja syarikat insurans (Bluedorn, 1982) serta di kalangan akauntan (Ferris \& Aranya, 1983). Schwyhart dan Smith (1972) dalam kajiannya menunjukkan kaitan antara komitmen kerja dengan kepuasan kerja yang menghasilkan korelasi positif dengan aspek-aspek kepuasan kerja termasuklah kepuasan dengan sesuatu firma, dengan kerja itu sendiri dan orang sekitarnya (Lodahl \& Kejner, 1965; Gannon \& Hendrickson, 1973) dan penyeliaan (Lodahl \& Kejner, 1965; Gannon \& Hendrickson, 1973). Kepuasan kerja juga didapati berkait rapat dengan kepuasan terhadap keperluan kepuasan diri dan kebebasan diri.

Kajian oleh Weissenberg dan Gruenfeld (1968) mendapati tiga pembolehubah penggalak iaitu pengiktirafan, pencapaian, dan tanggungjawab menjadi pemangkin kepada komitmen yang tinggi. Secara umumnya, kajian yang telah dilaksanakan menunjukkan wujud trend hubungan positif antara kepuasan kerja dengan komitmen terhadap organisasi. Hoppock (1935) melihat kepuasan kerja sebagai sesuatu yang berpunca dari keseragaman antara keperluan kerja dengan persekitarannya. Lawler dan Porter (1967) menyatakan bahawa kepuasan kerja mempunyai hubungan positif dengan prestasi kerja iaitu semakin tinggi tahap kepuasan kerja, semakin tinggi juga akan prestasi kerja. Vroom (1964) membuat kajian mengenai pangkat di kalangan pekerja kilang barangan elektronik mendapati bahawa ada hubungan positif antara kenaikan pangkat dengan kepuasan kerja. DeCotiis dan Summers (1987) menekankan bahawa ciri-ciri peribadi yang berdasarkan organisasi seperti tempoh perkhidmatan dan peluang kenaikan pangkat yang mempengaruhi komitmen terhadap organisasi. Powell (1990) menyatakan jika peluang naik pangkat rendah, niat meninggalkan organisasi akan meningkat. Beliau menekankan bahawa terdapat hubungan antara kepuasan berkaitan gaji dan peluang naik pangkat yang menjurus kepada niat untuk meninggalkan organisasi. Ciri-ciri ini berupaya mempengaruhi pekerja dalam membuat keputusan sama ada ingin terus bekerja dalam sesebuah organisasi atau sebaliknya.

Merujuk kajian Gruenberg (1980) mendapati perhubungan yang mesra dan saling bantu membantu dengan teman sekerja dan penyelia amat penting dan berkait rapat dengan kepuasan kerja. Rakan sekerja merujuk kepada individu atau kumpulan di mana seseorang pekerja bekerja bersama dalam sesuatu organisasi. Galloway, Boswll, Panckhurst dan Green (1984) mendapati bahawa hubungan baik dengan rakan sekerja merupakan faktor utama bagi meningkatkan kepuasan kerja di kalangan guru sekolah 
rendah New Zealand. Mottaz (1981) mendapati ciri-ciri organisasi peribadi dan organisasi mempunyai impak signifikan kepada komitmen terhadap organisasi, namun menekankan ciri organisasi lebih berkuasa. Ritzer dan Trice (1969) mendapati ciri-ciri organisasi adalah penentu utama dalam menentukan komitmen terhadap organisasi, sedangkan ciri-ciri peribadi tidak menjadi penentu.

Namun begitu, Luthan (1995) menyatakan tempoh perkhidmatan memberi kesan terhadap komitmen, lebih lama berkhidmat maka lebih setia dan komited seseorang individu disebabkan oleh ganjaran dan nilai kerja serta ramai kawan dan rakan rapat. Powell (1990) menyatakan jika peluang naik pangkat rendah, niat meninggalkan organisasi akan meningkat. Beliau menekankan bahawa terdapat hubungan antara kepuasan berkaitan gaji dan peluang naik pangkat yang menjurus kepada niat untuk meninggalkan organisasi. Tahap penyeliaan juga mempunyai hubungan signifikan dan negatif dengan niat untuk meninggalkan organisasi. Hackman dan Oldham (1975) mendapati bahawa bekerja tanpa penyeliaan ketat serta kuasa autonomi yang tinggi memberi impak menurunnya niat untuk meninggalkan organisasi. Hubungan antara rakan sekerja yang baik dan kuat boleh menurunkan niat untuk meninggalkan organisasi.

Mathieu dan Zajac (1990) mendapati kesan negatif yang kuat antara komitmen terhadap organisasi dengan niat untuk mencari pekerjaan alternatif serta niat untuk meninggalkan organisasi. Kamsiah (2003) melalui kajiannya kepada seramai 207 orang responden dari lima organisasi perkilangan elektronik di Kedah mendapati adanya hubungan yang signifikan antara ganjaran ekstrinsik (hubungan rakan sekerja, penyeliaan, gaji, kenaikan pangkat, persekitaran kerja) dengan komitmen terhadap organisasi. Nor Hartini (2004) pula mendapati terdapat hubungan yang signifikan faktor peluang kenaikan pangkat, penyelia dan rakan sekerja dengan komitmen organisasi yang melibatkan kakitangan di jabatan pelajaran. Manakala Gnana Sekaran (2007) mendapati kesemua dimensi kepuasan kerja iaitu gaji yang diterima, peluang kenaikan pangkat, penyelia, suasana kerja, rakan sekerja dan pekerjaan mempunyai hubungan yang signifikan dengan komitmen organisasi di kalangan pegawai JKR.

\section{KESIMPULAN}

Pekerja yang komited terhadap organisasi lebih cenderung untuk menghasilkan kerja yang bermutu, menunjukkan kadar pusing ganti (turn over) yang rendah, serta menunjukkan tahap tinggi untuk penglibatan dalam organisasi. Seandainya lebih komited seseorang individu terhadap organisasi, lebih banyak usaha dan tenaga akan dicurahkan oleh individu terbabit dalam menyempurnakan tugas yang menjadi tanggungjawabnya. Pekerja yang mempunyai komitmen tinggi akan kekal lebih lama dalam sesebuah organisasi. Dapatan kajian oleh beberapa pengkaji lain turut mendapati komitmen terhadap organisasi mempunyai hubungan positif dengan kepuasan kerja (Mowday et al, 1982). Komitmen memberi kesan terhadap organisasi melalui prestasi kerja yang diberikan oleh pekerja kepada organisasi.

\section{DAFTAR PUSTAKA}

Adam, J.S. (1965). Inequity in social exchanges. Advances in experimental social psychology. New York: Academic Press.

Ali, S. K. S., Hassan, M. F. H. \& Som, H. M. 2017. Tekanan Dan Kepuasan Kerja Dalam Kalangan Guru Pendidikan Jasmani. Journal of Global Business and Social Entrepreneurship (GBSE), 1(1), 122135.

Arnold, H.J., \& Feldman, D.C. (1986). Organizatinal behavior. New York: McGraw Hill.

Best, J.W., \& Kahn, J.V. (1998). Research in education. Eight edition. Boston: Allyn Bacon.

Ornstein, A.C., \& Hunkins, F.P. (2004). Curriculum. Foundations, Principles, and Issues. 4rd edition. Needham Heights: Allyn \& Bacon.

Robbins J. (2000), "The Price of Power: Essential services in Remote Indigenous Communities", Indigenous Law Bulletin, 4 (30), 4-6.

Mohd Salleh Lebar. (2003). Pendidikan guru di Malaysia masa kini: Perkembangan profesionalisme dan peningkatan yang berkualiti. http://www.ipbl.edu.my. Dicapai pada 30 Januari 2012. 
Powell, G. (1990). One More Time: Do Female and Male Managers Differ? Academy of Management Executive, 4 (3), 68-74.

Strauss, A. \& Corbin, J. (1994). Basics of qualitative research: Grounded theory procedures and techniques. Newbury Park, CA: Sage Publications, Inc.

Steers, R.M. (1977). Antecedents and Outcomes of Organizational Commitment. Administrative Science Quarterly, 22, 46-56.

Hall, D.T., Schneider, B., \& Nugren, H.T. (1970). Personal factors in organization identification. Administrative Science Quarterly, 15, 176-190.

Herzberg, F. (1966). Work and the nature of man. New York: The World Publishing Co.

Luthans, F. (1992). Organizational behaviour (7th ed.), New York, McGraw Hill Inc.

Vroom, V.H. (1964). Work and motivation. New York: Wiley. 